\title{
Laura Sigg: Investigating the Speciation, Bioavailability and Ecotoxicology of Trace Metals in Natural Waters
}

\author{
Bernhard Wehrli ${ }^{1,2} \cdot$ Philippe Behra ${ }^{3,4}$
}

Received: 11 May 2015/Accepted: 14 May 2015/Published online: 5 June 2015

(C) Springer Science+Business Media Dordrecht 2015

Laura Sigg is an internationally renowned expert in the aquatic geochemistry and ecotoxicology of trace metals. During her outstanding career as a researcher at Eawag, the Swiss Federal Institute of Aquatic Science and Technology, and adjunct professor at the Department of Environmental Systems Science of ETH Zurich, she pioneered the development of new theoretical concepts as well as practical methods for the assessment of the speciation, fate and effect of trace metals in the hydrosphere (Fig. 1). During his stay in Toulouse as invited professor some years ago, George Luther III proposed us to edit a special issue of Aquatic Geochemistry to honor our colleague Laura Sigg, who serves as a long-term associate editor of this journal. We were very happy to take up this challenge and invited people to submit original manuscripts to a special issue focusing on the fields of speciation, bioavailability and ecotoxicology of trace metals in natural waters. After being educated in chemistry with Paul W. Schindler at the University of Bern, where she learned the precision and rigor of experimental work and how to assess and synthetize ideas, Laura Sigg moved to Zurich and worked for her PhD with Werner Stumm. She started the first part of her career with ground-breaking research on thermodynamic models for adsorption processes at the solid-water interface and published two highly influential papers which became classics in this field (Stumm et al. 1980; Sigg and Stumm 1981).

Philippe Behra

philippe.behra@ensiacet.fr

Bernhard Wehrli

wehrli@eawag.ch

1 Eawag, Department Surface Waters, Seestrasse 79, 6047 Kastanienbaum, Switzerland

2 Institute of Biogeochemistry and Pollutant Dynamics, ETH Zurich, 8092 Zurich, Switzerland

3 Université de Toulouse; INPT, LCA (Laboratoire de Chimie AgroIndustrielle), UMR 1010, ENSIACET, 4 allée Émile Monso, CS 44362, 31030 Toulouse Cedex 4, France

4 INRA, LCA (Laboratoire de Chimie AgroIndustrielle), 31030 Toulouse, France 
Fig. 1 Laura Sigg at the 32nd IUPAC Congress, Stockholm, August 2-7, 1989 (photographed by $\mathrm{Ph}$. Behra)

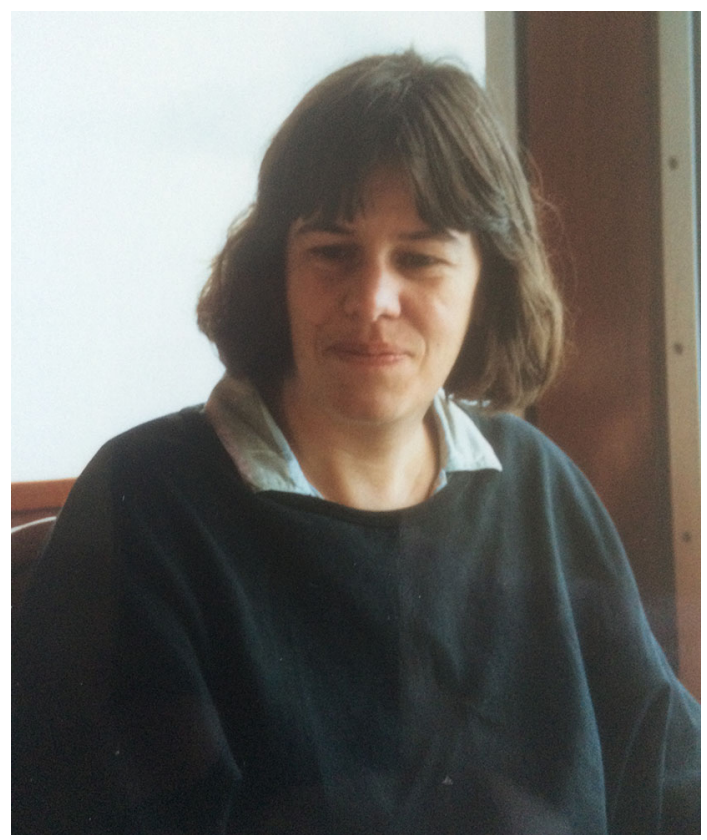

In the subsequent years, Laura Sigg developed an interest in the metal dynamics in natural waters. Her first $\mathrm{PhD}$ student, Beat Müller, worked on the adsorption of heavy metals to natural particles (Müller and Sigg 1990). At the same time, she contributed to an interdisciplinary project in Switzerland on "Forest Damage and Air Pollution" with a focus on the composition of gases, aerosols and fog waters: The main objective was to apply aquatic chemistry by combining thermodynamics and kinetics to better understand the composition of the air-liquid-solid atmospheric system (Behra and Sigg 1990).

During this period, she also met Hanbin Xue with whom she started collaborating on metal speciation in the aqueous phase by using voltammetric methods (Xue and Sigg 1993), and she expanded her research agenda to different systems such as agricultural catchments, rivers, lakes, ground water, roof runoff as well as a broad range of processes such as infiltration, vertical transport, settling of particles and seasonal redox reactions. She complemented such field observations with laboratory-based studies on the biogeochemical cycling of trace metals with a focus on the interaction between metal ions and particles (Fig. 2). Early on, her research group was thus studying the mechanisms of metal uptake by living cells, by considering in a first approach the living cell as a particle which can react at its surface as other functionalized surfaces (Xue et al. 1988). In this arena, Laura Sigg developed scientific leadership in the cross-comparison of field techniques for in situ trace metal speciation by using diffusion gradients in thin films (DGT) and other dynamic trace metal methods (Sigg et al. 2006).

Starting in 1988 a long-term collaboration between Laura Sigg and Renata Behra, research fellow at Eawag, changed the perception of geochemists regarding the interaction between trace metals or contaminants and living organisms in natural waters (Fig. 3). Together, and in collaboration with an expanding team, they first made significant progress in the understanding of the role of speciation in the bioavailability and the behavior of trace contaminants with respect to algae and periphyton (Knauer et al. 1997). 

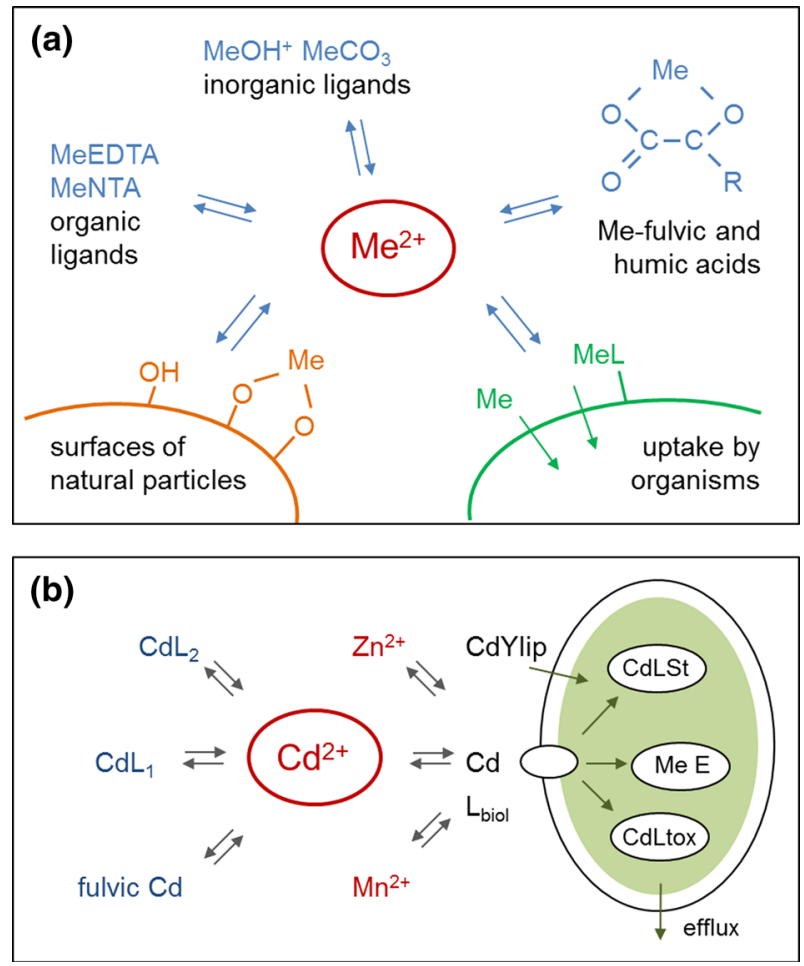

Fig. 2 Schematic representation of key processes defining a the speciation of metal ions in solution; $\mathbf{b}$ the speciation and uptake of trace metals by a simplified model of living cells (after L. Sigg)

Over the last decade, Laura Sigg and her team took the opportunity of combining interactions between colloids, i.e., manufactured nanoparticles such as $\mathrm{Ag}, \mathrm{CeO}, \mathrm{TiO}_{2}$, carbon nanotubes, and unicellular microorganisms, both of which can be considered as small particles. Colloids or manufactured nanoparticles are often functionalized at their surface by organic ligands or surfactant molecules in order to increase their stability in aqueous solution. On the other hand, microorganisms have membranes and/or cell walls which interact with molecules playing a similar role as functionalized colloids within their neighbor environment. In this way, Laura Sigg and her team made seminal contributions to the ecotoxicology of nanoparticles (Navarro et al. 2008).

As a multi-talented person Laura Sigg served as a highly respected editor of the journals Environmental Science and Technology and Aquatic Geochemistry being very much involved and thorough in her judgment. On the other hand, she wrote two important and popular textbooks one in German (Sigg and Stumm 2011) and the other one in French (Sigg et al. 2014).

The research completed under the guidance of Laura Sigg demonstrates the necessity of binding different disciplines together in order to understand the fate of trace contaminants in natural waters. Chemistry, and more specifically physical chemistry of interfaces, is of course one of the key points, but it is necessary to take into account the dynamics of the system, and the role of living organisms which may react by adapting themselves to new situations and change the local chemistry to survive. Changing perspectives between 
Fig. 3 Laura Sigg (left) and Renata Behra sampling periphyton (2001, photographed by David Kistler)

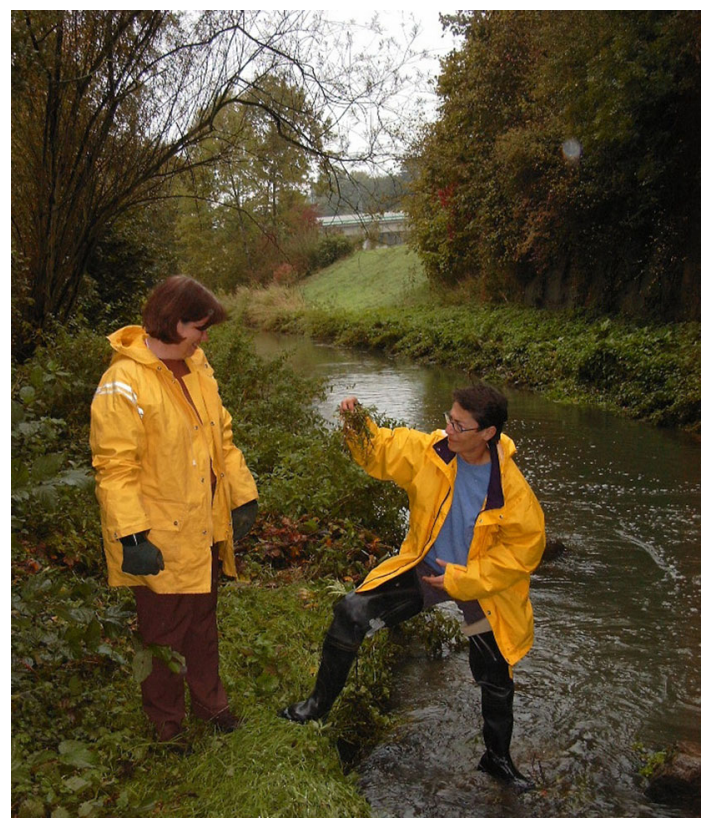

laboratory and field observations remains an essential ingredient of this type of research. In the future, the interaction between specialists in spectroscopy, trace analysis, molecular life sciences and modeling will be even more important. The papers published in this special issue provide a "tour d'horizon" of the field, and they illustrate a broad portfolio of research perspectives. The fifteen papers constituting this special issue can be grouped along five main topics:

1. Geochemistry of natural waters These studies document the state of the art of aquatic surface chemistry and cover aspects of light-induced redox cycling (Sulzberger 2015), acid-base equilibria on aluminum nanoparticles (Lützenkirchen et al. 2015) and adsorption of carboxylic acids onto goethite (Whitehead et al. 2015).

2. Biogeochemical cycles of trace metals in freshwater systems This section illustrates approaches based on field studies in lake sediments (Dittrich et al. 2015) and wetlands (Davranche et al. 2015) but covers also process-oriented research on redox kinetics of manganese oxides (Siebecker et al. 2015) and the role of metallophores in trace metal biogeochemistry (Kraemer et al. 2015).

3. Bioavailability of metals Worms et al. (2015) quantify the bioavailability of lead to microalgae in natural and laboratory systems and Domingos et al. (2015) review the challenge of assessing speciation and bioavailability in mixtures of dissolved ions.

4. Methods for analyzing speciation and bioavailability Recent years have seen significant advances in sampling techniques to analyze bioavailable fractions, such as ion exchange techniques (Crémazy et al. 2015) or samplers based on diffusive gradients in thin films (Davison et al. 2015). In addition, synchrotron-based X-ray spectroscopy offers molecular-level information on the coordination of trace metals in different matrices such as zinc in sediments (Webb and Gaillard 2015) or chromium in waste material (Delay et al. 2015). 
5. Ecotoxicology The final two publications of this issue illustrate ongoing research in the new field of nanotoxicology: Behra et al. (2015) compare the algal toxicity of gold nanoparticles and gold chloride, and Perstrimaux et al. (2015) analyze the effects of titanium dioxide particles on plankton in the Lagoon of Venice.

Taken together, the papers in this issue showcase the advances made over the past decades in understanding and predicting the behavior and fate of trace metals in the aquatic environment. As the "metallic footprint" of our technological societies increases, this knowledge is essential to safeguard the ecological functions of aquatic systems.

Acknowledgments We thank George Luther for his kind proposition to dedicate a special issue of Aquatic Geochemistry for honoring Laura Sigg and all the authors for their timely contributions. A large group of reviewers provided very constructive comments for improving all submitted manuscripts. The Foundation STAE (Sciences et Technologies pour l'Aéronautique et l'Espace) is also gratefully acknowledged for supporting Bernhard Wehrli during his stay in Toulouse. Finally, we thank Laura Sigg for all the ideas and methodological rigor she has provided to the field of aquatic biogeochemistry.

\section{References}

Behra P, Sigg L (1990) Evidence for redox cycling of iron in atmospheric water droplets. Nature 344:419-421

Behra R, Wagner B, Sgier L, Kistler D (2015) Colloidal stability and toxicity of gold nanoparticles and gold chloride on Chlamydomonas reinhardtii. Aquat Geochem 21(2-4):331-342

Crémazy A, Leclair S, Mueller KK, Vigneault B, Campbell PGC, Fortin C (2015) Development of an in situ ion-exchange technique for the determination of free $\mathrm{Cd}, \mathrm{Co}, \mathrm{Ni}$ and $\mathrm{Zn}$ concentrations in freshwaters. Aquat Geochem 21(2-4):259-279

Davison W, Lin C, Gao Y, Zhang H (2015) Effect of gel interactions with dissolved organic matter on DGT measurements of trace metals. Aquat Geochem 21(2-4):281-293

Davranche M, Gruau G, Dia A, Marsac R, Pédrot M, Pourret O (2015) Biogeochemical factors affecting rare earth element distribution in shallow wetland groundwater. Aquat Geochem 21(2-4):197-215

Delay M, Mangold S, Sembritzki R, Frimmel FH (2015) Chromium speciation in solid waste material and eluates by X-ray absorption spectroscopy and ion chromatography. Aquat Geochem 21(2-4):313-329

Dittrich M, Moreau L, Gordon J, Quazi S, Palermo C, Fulthorpe R, Katsev S, Bollman J, Chesnyuk A (2015) Geomicrobiology of iron layers in the sediment of Lake Superior. Aquat Geochem 21(2-4):123-140

Domingos RF, Gélabert A, Carreira S, Cordeiro A, Sivry Y, Benedetti MF (2015) Metals in the aquatic environment-interactions and implications for the speciation and bioavailability: a critical overview. Aquat Geochem 21(2-4):231-257

Knauer K, Behra R, Sigg L (1997) Effects of free $\mathrm{Cu}^{2+}$ and $\mathrm{Zn}^{2+}$ ions on growth and metal accumulation in freshwater algae. Environ Toxicol Chem 16:220-229

Kraemer SM, Duckworth OW, Harrington JM, Schenkeveld WDC (2015) Metallophores and trace metal biogeochemistry. Aquat Geochem 21(2-4):159-195

Lützenkirchen J, Marsac R, Casey WH, Furrer G, Kupcik T, Lindqvist-Reis P (2015) The effect of monovalent electrolytes on the deprotonation of small alumina polymorphs. Aquat Geochem 21(2-4):81-97

Müller B, Sigg L (1990) Interaction of trace-metals with natural particle surfaces-comparison between adsorption experiments and field measurements. Aquat Sci 52:75-92

Navarro E, Braun A, Behra R, Hartmann NB, Filser J, Miao AJ, Quigg A, Santschi PH, Sigg L (2008) Environmental behavior and ecotoxicity of engineered nanoparticles to algae, plants, and fungi. Ecotoxicology 17:372-386

Perstrimaux C, Le Faucheur S, Mortimer M, Stoll S, Aubry FB, Botter M, Zonta R, Slaveykova VI (2015) Stability of titanium dioxide nanoparticle agglomerates in transitional waters and their effects towards plankton from Lagoon of Venice (Italy). Aquat Geochem 21(2-4):343-362

Siebecker M, Madison AS, Luther GW (2015) Reduction kinetics of polymeric (soluble) manganese (IV) oxide $\left(\mathrm{MnO}_{2}\right)$ by ferrous iron $\left(\mathrm{Fe}^{2+}\right)$. Aquat Geochem 21(2-4):143-158

Sigg L, Stumm W (1981) The interaction of anions and weak acids with the hydrous goethite $(\alpha-\mathrm{FeOOH})$ surface. Colloids Surf 2:101-117 
Sigg L, Stumm W (2011) Aquatische Chemie, Einführung in die Chemie natürlicher Gewässer, 5th edn. Vdf, UTB, Zurich

Sigg L, Black F, Buffle J et al (2006) Comparison of analytical techniques for dynamic trace metal speciation in natural freshwaters. Environ Sci Technol 40:1934-1941

Sigg L, Behra P, Stumm W (2014) Chimie des milieux aquatiques, 5th edn. Dunod, Paris

Stumm W, Kummert R, Sigg L (1980) A ligand-exchange model for the adsorption of inorganic and organic-ligands at hydrous oxide interfaces. Croat Chem Acta 53:291-312

Sulzberger B (2015) Light-induced redox cycling of iron: roles for $\mathrm{CO}_{2}$ uptake and release by aquatic ecosystems. Aquat Geochem 21(2-4):65-80

Webb SM, Gaillard J-F (2015) Zinc speciation in contaminated sediments: quantitative determination of zinc coordination by X-ray absorption spectroscopy. Aquat Geochem 21(2-4):295-312

Whitehead CF, Carbonaro RF, Stone AT (2015) Adsorption of benzoic acid and related carboxylic acids onto $\mathrm{FeOOH}$ (goethite): the low ionic strength regime. Aquat Geochem 21(2-4):99-121

Worms IAM, Slaveykova VI, Wilkinson KJ (2015) Lead bioavailability to freshwater microalgae in the presence of dissolved organic matter: contrasting effect of model humic substances and marsh water fractions obtained by ultrafiltration. Aquat Geochem 21(2-4):217-230

Xue HB, Sigg L (1993) Free cupric ion concentration and Cu(II) speciation in a eutrophic lake. Limnol Oceanogr 38:1200-1213

Xue HB, Stumm W, Sigg L (1988) The binding of heavy-metals to algal surfaces. Water Res 22:917-926 